\title{
Processing Cultural Trauma: Intergenerational Effects of the Japanese American Incarceration
}

\author{
Donna K. Nagata* ${ }^{*}$, Jackie H. J. Kim, and Teresa U. Nguyen \\ University of Michigan, Ann Arbor
}

During World War II, the United States confined 120,000 Japanese Americans in incarceration camps based solely on their Japanese ancestry. Two thirds of those forced to live in the desolate camps were U.S. citizens. Decades later, the U.S. government concluded that Japanese Americans had suffered a grave injustice and issued a written apology and monetary award to each surviving incarceree. This article frames the incarceration as a race-based personal and cultural trauma that had enduring consequences for Japanese Americans. Critical impacts of this historic event on identity and postwar trauma coping among U.S.-born second generation Japanese American incarcerees and their offspring are described. We highlight how individual, intergenerational, and sociocultural processes interacted across decades to shape cultural trauma response and the movement to seek redress.

The mass incarceration of Japanese Americans represents one of the greatest violations of civil rights in U.S. history (Irons, 1983). Ten weeks after Japan's December 1941 military attack on Pearl Harbor, President Franklin D. Roosevelt authorized the removal of all persons of Japanese ancestry from the West coast based on the rationale that their proximity to Japan made them was potentially

\footnotetext{
${ }^{*}$ Correspondence concerning this article should be addressed to Donna K. Nagata, Department of Psychology, University of Michigan, Ann Arbor, MI 48109 [e-mail: nagata@umich.edu].

Donna K. Nagata, Department of Psychology, University of Michigan; Jackie H.J. Kim, Department of Psychology, University of Michigan; Teresa U. Nguyen, Department of Psychology, University of Michigan.

Teresa U. Nguyen is now at the Center for Women's Health and Health Disparities Research, University of Wisconsin, Madison.

The Nisei Project was funded by the University of Michigan Center for Japanese Studies, the University of Michigan Office of the Vice Provost for Academic and Multicultural Affairs, and the Civil Liberties Public Education Fund. The Sansei Project was funded through the Picker Fellowship at Smith College. Yuzuru Takeshita provided assistance with the Nisei Project recruitment and survey development. We thank the all those who generously volunteered to participate in this research.
} 
disloyal and capable of espionage or sabotage. Japanese Americans were ordered to leave their homes and live in remote incarceration camps for an average of 2-4 years. In total, 120,000 innocent men, women, and children were imprisoned without individual review or regard for their demonstrated loyalty to the United States; two thirds were young U.S.-born citizens. Although the term "internment" is often used to refer to this historical event, scholars have noted that this is a misnomer since "internment" refers to "the legally permissible detention of enemy aliens in time of war." The term "incarceration" is now considered to be more accurate (Densho, n.d.). Both terms are used in the current article, however, depending on the sources cited.

In 1980, President Jimmy Carter formed the Commission on Wartime Relocation and Internment of Civilians (CWRIC) to evaluate the circumstances surrounding the Japanese American removal. After reviewing hundreds of records and hearing testimonies from over 750 witnesses the commission concluded that the internment was not a military necessity but instead resulted from "race prejudice, war hysteria, and a failure of political leadership" (CWRIC, 1997, p. 18). Its final report documented the traumatic consequences of this event for Japanese American families. It also recommended that Congress acknowledge the injustice by passing a resolution of a written apology and one-time reparation payment of $\$ 20,000$ to each surviving incarceree. More than 40 years after the war, the Civil Liberties Act of 1988 successfully passed and approved the commission recommendations.

Governmental reparations countered the extant view that redress would not be possible due to the length of time between the wartime events and Commission findings. Such a view, however, takes a narrow view historical trauma and the consequences of racism. This article proposes that the incarceration trauma response be viewed broadly, as a process that emerged over decades through the interaction of personal, intergenerational, and social forces. The process is relevant to social issues concerning the long-term effects of racial prejudice and discrimination, the interplay between personal experience and political context, and policies around national security.

Individual trauma theory defines trauma as an event that shatters one's assumptive world, sense of self, and well-being (Caruth, 1995). Each Japanese American incarceree experienced these assaults. The massive ethnic targeting that characterized the incarceration also links this historical event to cultural trauma theory. Cultural trauma "occurs when members of a collectivity feel they have been subjected to a traumatic event that leaves indelible marks upon their group consciousness, marking memories forever and changing their future identity" (Alexander, 2004, p.1). Both individual and cultural trauma theories help us understand the intergenerational consequences of this historical event and how the pursuit of redress helped bridge ruptures in the individual and cultural identities of incarcerees and their offspring. We cite findings from two previous research 
studies to illustrate these frameworks. The Nisei Project included a national survey of 520 U.S.-born second generation (Nisei) Japanese Americans who had been incarcerated during the war. The Nisei were particularly important to study given their developmental stage as adolescents and emerging adults during incarceration and status as U.S. citizens. The survey obtained ratings on range of internmentrelated topics including levels of incarceration coping and suffering, redress relief, just world beliefs, and locus of control. Thirty participants also gave individual interviews on their experiences and reactions prior to, during, and after their incarceration, and views on receiving governmental redress. The second project, the Sansei Project, used a similar methodology to explore intergenerational incarceration consequences and surveyed 491 third generation (Sansei) Japanese Americans who had one or both parents incarcerated during the war. Forty-two Sansei gave individual interviews. This project focused on the nature of family internment communications, the impacts of the internment on their own and their parents' lives, and redress.

\section{Individual and Cultural Incarceration Traumas}

Japanese Americans had little more than 2 weeks' notice of their removal. Allowed to take only what could be carried, they were forced to abruptly leave behind homes, businesses, and belongings. Lack of information about where they were going, how long they would be gone, or what the government planned to do with them, magnified the trauma. Coded responses of Nisei project interviewees' recollections revealed predominant emotions of "shock," "worried," and "scared" for this time (Nagata, Cheng, \& Nguyen, 2012). Most Nisei faced two separate dislocations, first from their homes to humiliating temporary detention centers hastily set up in horse track stalls and livestock pavilions, then once more to the more permanent camps.

Confined in crowded army barracks surrounded by barbed wire, armed guards, and uninhabitable deserts, and swampland, camp inmates lived with entire families in a single room. Incarcerees ate and bathed in communal facilities, conditions that eroded privacy as well as traditional Japanese family relationships. Immigrant Issei (first generation) fathers lost their role as the primary provider. Issei mothers no longer cooked or cared for the home and the Nisei youth socialized more with peers than parents in the open mess hall and barrack-style living conditions (Morishima, 1973). In addition, camp governance, which required that official business be conducted in English, countered the traditional Japanese cultural value of age hierarchy and placed younger bilingual Nisei in more powerful positions over the older Japanese-speaking Issei.

One of the most significant stressors within the camps was a governmentimposed "loyalty questionnaire." All inmates 17 years or older were required to answer two questions, one which asked about willingness to serve in the armed 
forces of the United States (or the Women's Army Corps or the Army Nurse Corps for women and the Issei) and a second which asked each individual to "swear unqualified allegiance to the United States of America and faithfully defend the United States..." and forswear any form allegiance or obedience to the Japanese emperor, or any other foreign government, power or organization" (CWRIC, 1997, p. 192). Most incarcerees answered affirmatively to both questions and welcomed the opportunity to express their loyalty. Some Nisei not only answered affirmatively but also agreed to be drafted out of the camps and serve in segregated combat units or the military intelligence service. However, other incarcerees were bitter at being forced to proclaim loyalty to a country that treated them so unjustly. Responding "no" to the loyalty questions and resisting draft orders were two ways of expressing that anger. Still others worried that forswearing allegiance to Japan would be seen as indicating one's prior allegiance to Japan and retribution would follow. To add to the complexity, because Issei were barred from seeking citizenship in the United States, giving up allegiance to the Japanese emperor would leave them stateless.

Heated differences regarding the loyalty questions and the draft created powerful divisions even among family members. Nisei who were judged "loyal" based on their responses, became eligible for early relocation to the Midwest or East, while incarcerees whose answers were judged as reflecting questionable loyalty were segregated into Tule Lake, a more restrictive camp where draft resisters were jailed. The resisters and many "no" responders felt their actions demonstrated patriotism in a different way. They believed that it made no sense to pledge loyalty to or defend the United States while being denied their constitutional rights. However, many Japanese Americans accused them of being "un-American" and ostracized them for decades after the war. Only in the past 15 years has the community actively acknowledged their perspectives and made efforts to bridge the painful splits caused by the incarceration (Murray, 2008).

\section{Effects of Incarceration Trauma on Nisei Identity}

The wartime incarceration clearly fits Alexander's (2004) previous definition of cultural trauma: Members of a collectivity (Japanese Americans) experienced a traumatic upheaval (physically and emotionally) that changed their future identity. The impact on identity was particularly pronounced for the Nisei generation (Fugita \& Fernandez, 2004). An underlying racism driving the incarceration added to their sense of social and moral exclusion (Nagata, 1990) and is exemplified in the following comment from the general in charge of the Western Defense Command at the time "... (R)acial affinities are not severed by migration. The Japanese race is an enemy race and while many second and third generation Japanese born on United States soil, possessed of United States citizenship have become 'Americanized' the racial strains are undiluted" (CWRIC, 1997, p. 6). 
Strikingly, neither German Americans nor Italian Americans were subjected to mass incarceration even though the United States was also at war with Germany and Italy.

Although the incarceration assaults on identity represented a cultural trauma, Japanese Americans did not process them as a collective group. Instead, the impacts were contained primarily at the individual trauma level, during and after the war. The government's treatment represented a "betrayal by a trusted source" that led many American-born Nisei to "deep depression, a sense of shame, a sense of 'there must be something wrong with me' (Mass, 1991, p. 160)." This identity "double-bind" was especially powerful given that the majority of Nisei were in their teens and twenties when they were incarcerated (Yoo, 2000) and created a sense of "psychological uncertainty" (Fugita \& Fernandez, 2004), including feelings of humiliation and an internalized sense of self-blame that have been compared to those reported by rape victims (Hansen \& Mitson, 1974). Some Nisei felt that they were responsible for what had happened (Miyamoto, 1986; Nagata, 1993) as shown in the comments of one Nisei project participant:

\footnotetext{
Being labeled as an enemy alien and incarcerated in a concentration camp was the most traumatic experience of my life. There is still a feeling of bitterness which I will have the rest of my life. My thoughts at the time were: This country, which I loved and trusted, had betrayed me. How can they do this to me? What did we do to deserve this kind of treatment? Although I was only 15 years old, I could not believe that my country would do this to me, especially when I had been a proud and loyal American. As I sat in the barrack in camp, tears would flow whenever I thought about this.
}

Another shared: "I felt like a second class citizen, but it really confirmed, it really emphasized that I didn't belong in this country, that my face, my yellow face made the difference and I will never belong."

\section{Postwar Responses to the Incarceration Trauma}

After the war, Japanese Americans faced the daunting task of re-entering society and rebuilding their lives. The first Nisei who had been cleared to leave the camps were prohibited from returning to the West Coast and moved to cities such as Chicago and New York to take whatever employment they could find. Many worked as domestics or farmhands. The transition was anxiety-filled as they ventured into areas where Japanese Americans had not lived before, uncertain of the level of anti-Japanese sentiments they would encounter. Even efforts to seek social support from fellow Nisei proved challenging since the government advised them not live next to or congregate in public with other Japanese Americans. When the West Coast fully reopened for resettlement in December, 1944, those who returned to their previous regions of residence found that formerly thriving Japanese American communities had been permanently diminished (CWRIC, 1997). 
The Nisei coped by focusing on restarting their lives. Some distanced themselves from other Japanese Americans and anything related to Japan, a reaction that has been described as psychological identification with the aggressor (CWRIC, 1997; Mass, 1991). Others, distrustful of the broader U.S. society, preferred to associate only with other Japanese Americans. Data from the Nisei Project suggest that the latter within-group affiliation may have served a positive function: Survey participants who reported a stronger preference for associating with other Japanese Americans 50 years after the war also reported higher levels of positive emotional, economic, and physical coping in response to their incarceration trauma. The struggle in reconstructing their individual and cultural identities resembled those of Holocaust survivors' readjustment processes, including tensions about assimilation and the silencing of their incarceration stories (Schwartzman, 2015).

In fact, a key Nisei response was the suppression their Japanese cultural identity and attempt to blend into American culture (Ima, 1976). "By trying to prove we were 110 percent American," noted Mass (1991), "we hoped to be accepted" (p.161). Rather than expressions of anger, sadness or feelings of injustice, silence about the incarceration pervaded the postwar response of Nisei and the Japanese American community (CWRIC, 1997; Kashima, 1980). The detachment, silence, and avoidance of trauma-related stimuli paralleled symptoms of posttraumatic stress (Loo, 1993) - symptoms that have been observed in survivors of other historical traumas (Apfelbaum, 2000; Danieli, 1998; Schwartzman, 2015). Japanese cultural values encouraging emotional restraint, a fatalistic view on life that discourages dwelling on the past characterized by the phrase "shikata ga nai" ("It cannot be helped"), as well as an emphasis on "gaman" (to endure and persevere) further discouraged discussion. Silence about the camps represented a "social amnesia" to suppress unpleasant memories and feelings (Kashima, 1980).

An absence of attention to the incarceration in textbooks and the media, combined with the Nisei generation's relatively strong postwar socioeconomic standing, suggested to many that Japanese Americans were a "model minority" who had risen from prejudice with no obvious lasting negative effects of the incarceration (Nakanishi, 1993). However, their silence about the incarceration and efforts to "prove" themselves to a home country that unjustly imprisoned them took a critical toll. Research suggests that avoiding discussion of trauma experiences over an extended period of time can negatively affect physical health (Pennebaker, Barger, \& Tiebout, 1989). Mass (1976) hypothesized that the prevalent psychosomatic disorders, peptic ulcers, and depression she observed within the postwar Nisei population stemmed from their suppression and repression of incarceration experiences. Jensen (1997) also found that former incarcerees had more than two times greater risk of cardiovascular disease than did their noninterned counterparts. This serious physical toll, particularly prevalent among Nisei men, was mentioned by a Sansei interviewee as well: 
I think that many Nisei have died early of various diseases (my father included. He had cancer at 40 and died at 54). I really strongly believe that the trauma of incarceration had a physiological effect on them. Most of my Japanese American friends' fathers have died before the age of 60" (Nagata, 1993, p. 141).

Among Sansei survey respondents, twice as many formerly incarcerated fathers had died before the age of 60 compared to fathers who had not been incarcerated. Nagata (1993) hypothesized that the incarceration prevented Nisei men both from accomplishing key gendered developmental tasks and subjected them to the indignity of ostracism and wrongful imprisonment, a view expressed by one Nisei Project interviewee: "It's not like you're growing gradually into manhood and you're following a set pattern in life, you know, it's different. You cut it off and then you start all over again. It's very difficult, very, very difficult to do that." These circumstances are compounded when the roles of men as male protector and provider are undermined, a point raised by Holocaust researchers who have also noted more negative impacts on male survivors than female survivors (Nadler \& Ben-Sushan, 1989).

\section{Intergenerational Incarceration Trauma Effects}

Postwar Nisei responses had critical intergenerational impacts for their Sansei children, the majority of whom were born after the war. Family avoidance of what Nisei parents had endured created a "conspiracy of silence" observed in trauma survivor groups across the world (Danieli, 1998) that created a significant gap in the Sansei's personal history and identity development (Miyoshi, 1980; Nagata, 1993). Sansei project participants confirmed the pervasiveness of this silence, reporting that they grew up hearing about the incarceration only in indirect or cryptic ways. Parents often mentioned it as a vague and general reference point in time using phrases such as "before camp" and "after camp," or shared positive or humorous memories. From the Nisei's perspective, the lack of communication reflected an attempt to circumvent burdening their children with knowledge about what had happened. As one Nisei interviewee shared, "I want them to grow up straight and tall and beautiful as they can, without all the sadness, sort of branding them that they are different".

Such efforts to protect the next generation, however, did not fully succeed. Sansei interpreted their parents' reluctance to talk about the camps as signaling something too painful to discuss (Nagata, 1993). Parental silence about trauma can have negative consequences for the next generation (Wiseman et al., 2002) and data from the Sansei Project found partial support for this relationship. Lower levels of Nisei parents' incarceration communication were associated greater perceived familial distance and lower reports of positive impacts stemming from a parent's incarceration. Interestingly, greater levels of parental incarceration communication were associated with higher reported levels of anger and sadness, suggesting 
that while greater communication may have helped Sansei feel closer to their parents by hearing more about their camp experiences, greater emotional distress accompanied that knowledge.

The Nisei parents' efforts to blend into the mainstream, prove themselves, and minimize associations with Japan also affected the Sansei generation's life views. Sansei interviewees reported an "inherited" need to become "super" American and downplay their Japanese identity and culture, "not rock the boat" to avoid drawing attention to themselves, and prove their worth to society through high achievement and hard work: "I think the internment has influenced all our lives even though we do not talk about it much. Our need to achieve, to prove ourselves American, our feelings of self-worth all have been influenced by the mass rejection we were subjected to" (Nagata, 1993, p. 138). Some viewed the strong emphasis on education as representing their parents' attempt to ensure their children's future security. However, one Sansei interviewee's father stressed education for a very different reason: "People can take everything you own. They can even put you in prison, but they can't take away what's inside your head" (Nagata, 1993, p. 138).

The suppression of Japanese heritage also resulted in the Sansei losing connection with the Japanese language and cultural practices at an accelerated rate, as noted by one interviewee: "A lot of people (Sansei) didn't even grow up like they were Japanese and it was conscious, you know" (p. 138). The loss of Japanese language and weakened ethnic communities, however, did not necessarily diminish their sense of ethnic identity (Fugita \& O'Brien, 1991). Ethnic identity involves a broader process of recognizing the cultural differences between one's own group and the dominant group (Phinney, 1990). The incarceration remained a powerful reminder of those differences, as did the fact that the Sansei remained racially distinct from the mainstream society even as they were urged to "blend in" and assimilate. Writer David Mura (1991) suggested that the third generation as a whole inherited "instead of Japaneseness, a sense of shame" (p. 218). While the majority of Sansei coped with these negative effects, the consequences were devastating among some who did not or could not live up to their Nisei parents' expectations and resorted instead to drug abuse, suicide, and gang activities (Mass, 1976; Tanaka, Nako, \& Mabalot, 1999).

Sansei interviewees identified additional cross-generational impacts. All wondered how their lives would be different if their parents had not been incarcerated, aware of the economic impacts of lost farmlands and livelihoods. Others were haunted by questions about how the camps robbed Nisei parents of their potential and confidence:

He's (my father) been a gardener since (the war). He's never really used his artistic talent ... He was a fine artist, so that part is sad. He could have been a much more influential person, a much more self-satisfied person, maybe having his own company or being a much more successful person... My father was never proud to be a gardener... As a result, we never really talked about what our father did for a living (Nagata, 1993, p. 143). 
Every Sansei interviewee expressed sadness over their parents' losses. Some attempted to counteract the sadness by pursuing careers to finish the "unfinished dreams" of their mother or father or attending the university where a parent had been unable to complete their education. Still others pursued careers as lawyers or community activists to address issues of social injustice. Although the majority of intergenerational trauma effects were negative, Sansei project participants noted positives as well. Virtually all expressed admiration for their parents' resiliency and ability to cope with the camp experience and view their parents as positive role models for their own lives.

\section{Processing Cultural Trauma: From Silence to Resurrection and Redress}

Alexander (2004) notes that a "trauma process" must take place to bridge the gap between a cultural trauma and its social representation. Trauma, he suggests, is not simply the consequence of a group's experience of pain. Instead, "it is the result of this acute discomforting entering into the core of the collectivity's sense of its own identity" (p. 10). While the silence within Japanese American families represented an attempt to repress the incarceration trauma for more than three decades, the movement toward a social representation of what occurred required a new master narrative among Japanese Americans as a whole, one that publicly claimed the significance of the event. The agents of this aspect of trauma processing typically come from a key "carrier group," often the next generation, that is situated in the social structure to articulate such claims in the public sphere (Alexander, 2004). For Japanese Americans, the Sansei were a carrier group who could bring attention to the incarceration trauma, encourage former incarcerees to break their silence, and facilitate the seeking of governmental redress for the injustice.

The Sansei were better situated than the Nisei to bring the incarceration into public and community awareness. They were motivated to fill in the gaps in their family histories that had been created by the Niseis' silence and had witnessed their parents' unresolved pain. Most had not directly experienced the camps and therefore did not carry the intensity of personal trauma from that event. More acculturated to U.S. society, the Sansei were also less inhibited about verbalizing their views in public. Additionally, the mid-1960s Black Power movement led young Japanese Americans to take ethnic studies classes, redefine their group identity, and see the incarceration as their own history of racial oppression similar to that shared by other racial minorities (Maki, Kitano, \& Berthold, 1999; Nakanishi, 1993). By the late 1960s, this newly formed ethnic identity encouraged Sansei to re-engage with their wartime past by participating in a range of internment-related activities including annual pilgrimages to the sites of former camps (Nakanishi, 1993) and Days of Remembrance. 
The Civil Rights movement also helped Japanese Americans publicly claim the incarceration trauma through the concerns raised in the late 1960s by African American leaders regarding Title II of the 1950 Internal Security Act (Nakanishi, 1993). Title II, which referenced the Japanese American camps, created the legal apparatus to establish concentration camps for holding individuals, "without benefit of a trial, but merely by executive fiat ..." because that individual "might be thinking about engaging in espionage or sabotage" (Okamura, Takasugi, Kanno, \& Uno, 1974, p. 73 as cited by Nakanishi, 1993). African American leaders were concerned that Title II could justify the confinement of individuals linked to ghetto riots and anti-war demonstrations at the time and launched efforts to have it repealed. Japanese Americans, serving as the one group in the country uniquely positioned to legitimately seek its repeal, had a pivotal role in successfully repealing the act (Uno, 1974). Attention drawn by Title II also broadened support for addressing the wrongfulness of the wartime incarceration among Americans, generally, and within the Japanese American community. By the time the CWRIC formally investigated the 40-year-old wartime injustice, the cultural trauma of incarceration could be represented in public manner. About the same time, Sansei lawyers also brought attention to the injustice through their efforts to vacate the earlier wartime convictions of Japanese Americans who had been jailed for violating evacuation and curfew orders (Irons, 1989) and calls for redress escalated.

The redress movement was not fully embraced by all Japanese Americans. Surveys, including those for the Nisei and Sansei Projects, indicated approximately 80 percent Japanese American support for seeking reparations (Fugita \& O’Brien, 1991; Maki et al., 1999; Nagata, 1993). Those against it worried that redress demands could create a backlash, counteracting the years of effort spent on establishing a positive image in the mainstream society. "Among many of my peers," noted one Nisei interviewee, "they were saying 'Well, don't make waves or we'll get the hakujin (Caucasians) to get mad at us again' type of thing." Others felt that seeking monetary compensation would cheapen the suffering and sacrifice they had endured. Still others did not want to risk being rebuffed yet again by the government.

Ultimately, however, the move toward redress legislation created new and positive opportunities for Japanese Americans to address the incarceration trauma, and served as a form of trauma recovery that allowed them to move from selfblame to public systems-blame and develop a sense of self-efficacy and mastery (Loo, 1993). Seeking redress also helped remove the sense of shame, provided the Japanese American community "an avenue for individual and collective catharsis" (Fugita \& Fernandez, 2004, p. 205), and increased a sense of pride by standing up for themselves (Maki et al., 1999).

When Nisei Project survey respondents were asked to rate $(1=$ not at all, $7=$ a great deal) the degree to which they felt the passage of redress legislation brought relief, there were moderately positive reactions to receiving redress (average 
ratings were between 3 and 4) with the strongest positive redress impact related to increased faith in the government (mean $=5.18$ ). This increase is important given that the Nisei had grown up in a society where, as noted by one interviewee "We always had the feeling of being kicked around" and learned to expect exclusion from justice (Nagata, 1990). The lowest reported positive impacts occurred in relation to reducing negative feelings about their past incarceration (mean $=$ 3.34 ) and relieving physical suffering from those years (mean $=3.27$ ). These findings, as well as the fact that emotions of "angry/bitter" were mentioned by more than $40 \%$ of Nisei project interviewees when discussing their postincarceration perspectives (Nagata et al., 2012), suggest important limits of reparation and the enduring impacts of historical trauma.

Similar to the intragroup and intragenerational differences found in lived experiences of other historical events (e.g., Stewart, Winter, Henderson-King, \& Henderson-King, 2015, re. the 1960s), project data also indicated within-group variation in reactions to receiving redress. Nisei women, older respondents, those with lower income, and those with a greater preference for other Japanese Americans reported the greatest redress benefits (Nagata \& Takeshita, 2002). Buddhist participants also reported significantly greater levels of personal redress benefits (emotionally, physically, and economically) compared to Christian participants (Wu, Kim, \& Nagata, 2014) and Nisei with stronger beliefs that the world is just (Lerner, 1980) reported more positive effects from redress (Kim, Nagata, \& Akiyama, 2014). The differences indicate the relevance of individual differences in assessing redress impacts.

Other scholars have corroborated many of the Nisei and Sansei project findings (Fugita \& Fernandez, 2004; Miyoshi, 1980). However, our cross-sectional data are limited by offering perspectives from only one point in time. Nisei participants were recruited from camp reunion lists and Sansei participants were recruited primarily from the Japanese American Citizens League organization (JACL; see Kim et al., 2014; Nagata, 1993), limiting the generalizability of findings. Similarly, the respondents' narratives do not capture all perspectives from the incarceration experience or of redress. Data are missing from those who did not attend camp reunions or join the JACL. These individuals may have avoided these organizations after experiencing particularly negative experiences in the camps and/ or within the Japanese American community (e.g., draft resisters and those who answered negatively to the loyalty oath). Their perspectives are needed to provide a more complete understanding of the incarceration.

\section{Summary and Implications}

Ethnic and racial minority groups faced unique burdens during World War II (see Hunter \& Rollins, 2015, re. the Tuskegee airmen). For Japanese Americans, the war's burdens included the U.S. government's unjust incarceration of thousands 
of innocent citizens based only on their ethnic heritage. The presented research documents the powerful negative consequences of this experience for the identity of those who were imprisoned and their offspring. It took Japanese Americans over four decades to overcome silence about what they had endured, reassert their identity, and pursue governmental redress. The eventual receipt of an apology and payment had positive impacts overall, although the strength and nature of personal redress benefits varied across individuals.

Intercultural relations with outside groups played a critical role in the Japanese American response to historical trauma. African American activists, President Carter, and other non-Japanese American allies played positive roles in advancing the healing process and suggest the benefit of intergroup dialogues that encourage awareness about historical traumas. Those that emotionally appeal to allies situated in privileged positions in the majority culture (Greenwood, 2015) can create strong cross-cultural coalitions that help the traumatized group regain part of what may have felt was lost in history or in silence.

Intercultural support was powerful in addressing the incarceration trauma but the burden of healing lay with Japanese Americans themselves. The process took decades given the understandable reluctance of incarceration survivors to engage with their past. Eventually, however, their postwar children who had continued to experience the effects of their families' camp experience, developed a new cultural identity that sought justice for past wrongdoing and helped ignite the movement to seek governmental redress. Our findings show how response opportunities that are unavailable to survivors initially may become available through the next generation.

Ultimately, the documented consequences of the incarceration trauma have implications for policy and social action. The Supreme Court has never overruled or formally discredited the government's legal deference to the restriction of constitutionally protected liberties when it claims military necessity. Yamamoto and Serrano (2002) consider the U.S. government's more recent post 9/11 targeting of Arab Americans and Muslims as evidence that the incarceration was not a historical aberration. Legal challenges, political education and community organizing, they argue, are essential in shaping policy around concerns about national security. The negative impacts linked to the Japanese American experience show that disregard for civil liberties when reacting to national security concerns causes serious damage. Policy makers must be proactive, rather than reactive, in addressing these concerns.

\section{References}

Alexander, J. C. (2004). Toward a theory of cultural trauma. In J. C. Alexander, E. Eyerman, B. Giesen, N. J. Smelser \& P. Sztompka (Eds.), Cultural trauma and collective identity (pp. 1-30). Berkeley, CA: University of California Press. 
Apfelbaum, E. R. (2000). And now what, after such tribulations? Memory and dislocation in the era of uprooting. American Psychologist, 55, 1008-1013.

Caruth, C. (1995). (Ed.) Trauma: Explorations in memory. Baltimore, MD: John Hopkins University Press.

Commission on Wartime Relocation and Internment of Civilians. (1997). Personal justice denied: Report of the Commission on Wartime Relocation and Internment of Civilians. Washington DC: The Civil Liberties Public Education Fund and Seattle, WA: University of Washington Press.

Danieli, Y. (1998). (Ed.) International handbook of multigenerational legacies of trauma. NY: Plenum.

Densho. (n.d.) Retrieved on April 10, 2015 from: (http://densho.org/assets/sharedpages/bookmarkThis. asp? $\mathrm{u}=\% 2 \mathrm{Fdefault} \% 2 \mathrm{Easp} \% 3 \mathrm{Fpath} \% 3 \mathrm{D} \% 2 \mathrm{Fassets} \% 2 \mathrm{Fsharedpages} \% 2 \mathrm{Fglossary} \% 2 \mathrm{Easp} \&$ $\mathrm{t}=$ Terminology+and+Glossary\&s $=$ home $)$.

Fugita, S. S., \& Fernandez, M. (2004). Altered lives, enduring communities: Japanese Americans remember their World War II incarceration. Seattle: University of Washington Press.

Fugita, S. S., \& O'Brien, D. J. (1991). Japanese American ethnicity: The persistence of community. Seattle, WA: University of Washington Press.

Greenwood, R. M. (2015). Remembrance, responsibility, and reparations: The use of emotions in talk about the 1921 Tulsa race riot. Journal of Social Issues, 71(2), 338-355.

Hansen, A. A., \& Mitson, B. E. (1974). Voices long silent: An oral inquiry into the Japanese American evacuation. Fullerton, CA: Japanese American Project of the Oral History Program at California State University.

Hunter, A. G., \& Rollins, A. (2015). We made history: Collective memory and the legacy of the Tuskegee airmen. Journal of Social Issues, 71(2), 264-278.

Ima, K. (1976). Japanese Americans: The making of "good" people. In A. G. Dworkin \& R. J. Dworkin (Eds.) The minority report: An introduction to racial, ethnic, and gender relations (pp. 254-296). NY: Praeger.

Irons, P. (1983). Justice at war: The story of the Japanese American internment cases. NY: Oxford University Press.

Irons, P. (1989). (Ed.) Justice delayed: The record of the Japanese American internment cases. Middleton, CT: Wesleyan University Press.

Jensen, G. M. (1997). The experience of injustice: Health consequences of the Japanese American internment. Ph.D. Dissertation, University of Colorado, Department of Anthropology.

Kashima, T. (1980). Japanese American internees: Return, 1945-1955: Readjustment and social amnesia. Phylon, 41, 107-115.

Kim, J. H. J., Nagata, D. K., \& Akiyama, M. (2014). Japanese American reactions to World War II incarceration redress: Just world beliefs, locus of control, and coping. Cultural Diversity and Ethnic Minority Psychology, doi:10.1037/a0037629.

Lerner, M. J. (1980). The belief in a just world: A fundamental delusion. NY: Plenum.

Loo, C. M. (1993). An integrative-sequential treatment model for posttraumatic stress disorder: A case study of the Japanese American internment and redress. Clinical Psychology Review, 13, 89-117.

Maki, M. T., Kitano, H. H. L., \& Berthold, S. M. (1999). Achieving the impossible dream: How Japanese Americans obtained redress. Urbana, IL: University of Illinois Press.

Mass, A. I. (1976). Asians as individuals: the Japanese community. Social Casework, March, 160-164.

Mass, A. I. (1991). Psychological effects of the camps on the Japanese Americans. In R. Daniels, H. H. L. Kitano \& S. C. Taylor (Eds.), Japanese Americans: From relocation to redress (Rev. ed., pp. 159-162). Salt Lake City: University of Utah Press.

Miyamoto, S. F. (1986). Problems of interpersonal style among the Nisei. Amerasia Journal, 13, 29-45.

Miyoshi, N. (1980). Identity crisis of the Sansei and the American concentration camp. Pacific Citizen, $91,41-42,50,55$.

Morishima, J. K. (1973). The evacuation: Impact on the family. In S. Sue \& N. N. Wagner (Eds.), Asian Americans: Psychological perspectives (pp. 13-19). Palo Alto, CA: Science and Behavior Books.

Mura, D. (1991). Turning Japanese: Memoirs of a Sansei. NY: Atlantic Monthly Press. 
Murray, A. Y. (2008). Historical memories of the Japanese American internment and the struggle for redress. Stanford, CA: Stanford University Press.

Nadler, A., \& Ben-Sushan, D. (1989). Forty years later: Long-term consequences of massive traumatization as manifested by Holocaust survivors from the city and the kibbutz. Journal of Consulting and Clinical Psychology, 57, 287-293.

Nagata, D. K. (1990). The Japanese American internment: Perceptions of moral community, fairness, and redress. Journal of Social Issues, 46, 133-146.

Nagata, D. K. (1993). Legacy of injustice: Exploring the cross-generational impacts of the Japanese American internment. New York: Plenum.

Nagata, D. K., Cheng, W. J. Y., \& Nguyen, T. U. (2012). Recollections of historical injustice: A qualitative investigation of emotions in Japanese American incarceration memories. In D. K. Nagata, L. Kohn-Wood \& L. A. Suzuki, (Eds.), Qualitative strategies for ethnocultural research (pp. 103-118). Washington, DC: American Psychological Association.

Nagata, D. K., \& Takeshita, Y. (2002). Psychological reactions to redress: Diversity among Japanese Americans interned during World War II. Cultural Diversity and Ethnic Minority Psychology, $8,41-59$.

Nakanishi, D. T. (1993). Surviving democracy's mistake: Japanese Americans and the enduring legacy of Executive Order 9066. Amerasia Journal, 19, 7-35.

Okamura, R., Takasugi, R., Kanno, H., \& Uno, E. (1974). "Background and history of the repeal campaign"- Campaign to repeal the Emergency Detention Act. Amerasia Journal, 2, 71-111.

Pennebaker, J. W., Barger, S. D., \& Tiebout, J. (1989). Disclosure of trauma and health among Holocaust survivors. Psychosomatic Medicine, 51, 577-589.

Phinney, J. S. (1990). Ethnic identity in adolescents and adults: Review of research. Psychological Bulletin, 108, 499-514.

Schwartzman, R. (2015). Sutured identities in Jewish Holocaust survivor testimonies. Journal of Social Issues, 71(2), 279-293.

Stewart, A. J., Winter, D. G., Henderson-King, D., \& Henderson-King, E. (2015). How politics become personal: Sociohistorical events and their meanings in people's lives. Journal of Social Issues, 71(2), 294-308.

Tanaka, J., Nako, J., \& Mabalot, L. (1999). When you're smiling: The deadly legacy of internment. Los Angeles, CA. Visual Communications/Asian American Studies Central.

Uno, E. (1974). Therapeutic and educational benefits (a commentary). Amerasia, 2, 109-111.

Wiseman, H., Barber, J. P., Raz, A., Yam, I., Foltz, C., \& Livne-Snir, S. (2002). Parental communication of Holocaust experiences and interpersonal patterns in offspring of Holocaust survivors. International Journal of Behavioral Development, 26, 371-381.

Wu, K., Kim, J. H. J., \& Nagata, D. K. (2014). Redress relief among Christian and Buddhist Japanese American incarceration survivors. Poster presented at the Third Biennial Division 45 Research Conference. Eugene, OR.

Yamamoto, E. K., \& Serrano, S. K. (2002). The loaded weapon. In R. C. Leong \& D. T. Nakanishi (Eds.) Asian Americans on war and peace (pp. 51-62). Los Angeles: UCLA Asian American Studies Center Press.

Yoo, D. K. (2000). Growing up Nisei: Race, generation, and culture among Japanese Americans in California 1924-1949. Urbana \& Chicago, IL: University of Illinois Press.

DONNA K. NAGATA is Professor of Psychology at the University of Michigan, Ann Arbor. She received her PhD in Clinical Psychology from the University of Illinois, Urbana-Champaign. Her research focuses on Asian American mental health with an emphasis on family processes and emotional distress, and the long-term psychosocial consequences of the World War II Japanese American incarceration. Additional research interests include qualitative methods in ethnocultural research. 
JACKIE H. J. KIM, MS, is a doctoral student of the Department of Psychology at the University of Michigan. Her primary research interests are focused on areas related to Asian American and immigrant mental health including: culturally relevant assessment and treatment methods; depressive and posttrauma symptomatology; stigma and help-seeking behaviors; and the association between psychological distress and related physical health conditions. Recent work also examines Japanese American incarceration survivors' reactions to redress.

TERESA U. NGUYEN, PhD, is a Postdoctoral Fellow at the Center for Women's Health and Health Disparities Research, University of Wisconsin, Madison. Her primary research interests include ethnocultural mental health, Asian American mental health, minority and immigrant psychology, cultural conceptualization and subjective experiences of emotion, Vietnamese Americans and the psychosocial consequences of the Vietnam War and refugee experiences, intergenerational relations, and family interaction processes. 